\title{
COMMUNITY-BASED TOURISM VILLAGE DEVELOPMENT STRATEGIES: A CASE OF BOROBUDUR TOURISM VILLAGE AREA, INDONESIA
}

\author{
Arintoko ARINTOKO* \\ Universitas Jenderal Soedirman, Faculty of Economics and Business, Department of Economics and Development \\ Studies, Jl. H.R. Bunyamin 708, Grendeng, Purwokerto, Indonesia, e-mail: arintokoz@yahoo.co.id
}

\begin{abstract}
Abdul Aziz AHMAD
Universitas Jenderal Soedirman, Faculty of Economics and Business, Department of Economics and Development Studies, Jl. H.R. Bunyamin 708, Grendeng, Purwokerto, Indonesia, e-mail: rekan.aziz@gmail.com
\end{abstract}

\section{Diah Setyorini GUNAWAN}

Universitas Jenderal Soedirman, Faculty of Economics and Business, Department of Economics and Development Studies, Jl. H.R. Bunyamin 708, Grendeng, Purwokerto, Indonesia, e-mail: diahsetyorini943@gmail.com

\author{
Supadi SUPADI \\ Universitas Jenderal Soedirman, Faculty of Economics and Business, Department of Economics and \\ Development Studies, Jl. H.R. Bunyamin 708, Grendeng, Purwokerto, Indonesia
}

Citation: Arintoko, A., Ahmad, A.A., Gunawan, D.S. \& Supadi, S. (2020). COMMUNITYBASED TOURISM VILLAGE DEVELOPMENT STRATEGIES: A CASE OF BOROBUDUR TOURISM VILLAGE AREA, INDONESIA. GeoJournal of Tourism and Geosites, 29(2), 398413. https://doi.org/10.30892/gtg.29202-477

\begin{abstract}
The concept of community-based tourism village development becomes important in the sustainable tourism development strategy part. The study aims to formulate a community-based tourism village development strategy with a case in the Borobudur tourism village area. The research uses strengths, weaknesses, opportunities, and threats (SWOT) approaches. The identification of factors was obtained from field observations, interviews, and focus group discussions with key elements of the community and stakeholders. The results showed that the strength and opportunities factors had an importance score and the percentage of agreement was higher than the weakness and threat factors. Community-based tourism village development strategies can be carried out with more emphasis on strategies that rely on strengths and opportunities, through S-O and W-O strategies, relative to weaknesses and threats, through $\mathrm{S}-\mathrm{T}$ and $\mathrm{W}-\mathrm{T}$ strategies. However, the implementation of the four strategies is still being carried out because they will complement each other in order to achieve the goal of the development of a tourism strategic area through community-based tourism villages.
\end{abstract}

Key words: tourism village; community-based tourism, SWOT approaches

\footnotetext{
* Corresponding author
} 


\section{INTRODUCTION}

Today, the development of tourism has attracted much attention throughout the world because tourism has developed into an industry that provides many benefits for both the host and visitor. The general and rapid development caused by the development of tourism has become a dynamic social and economic phenomenon, affecting many countries and communities. This phenomenon has created many unexpected economic, socio-cultural and environmental impacts, both on the host community and visiting tourists (Choi \& Sirakaya, 2005; Archer et al., 2005). In the macroeconomic context, at present, the tourism sector has become a major source of income for many countries.

The economic benefits of tourism, especially in developing countries are felt when these benefits can be enjoyed by the community. Tourism in developing countries can be seen as an industry that can provide much-needed economic benefits in rural and remote areas where people who lack the knowledge and financial resources can take part in the development of tourism without external support (Yanes et al., 2019).

Furthermore, tourism can be used as an approach for sustainable rural development as in the study of Petrović et al. (2017). Rural tourism is given special priority in the national sustainable development strategy because it is observed as a high potential sector with a vertical institutional structure that supports its development. Rural tourism has the potential to be developed and become a strategy in sustainable national development, especially in developing countries where most of the population is in rural areas that have natural, cultural and indigenous life. Sustainable tourism can enhance the country's overall identity because it is closely related to the methods of local production, the lives of local residents, cultural celebrations, heritage and nature tourism in rural or suburban areas (Everett \& Aitchison, 2008; Petrović et al., 2017). In addition, this type of tour is a very attractive alternative for different tourist segments, whose preferences include the sustainability of tourism when planning their trips. During the visit to the destination, visitors can experience attractions in the area and the possibility that positive experiences will influence the possibility of return visits (Komppula, 2014).

The latest development in the study of tourism is the popularity of communitybased tourism (CBT) in developing countries, especially for rural communities (Muganda et al., 2010). Many villages are able to host with good natural resources and great potential for tourism development (Hiwasaki, 2006). The concept of community-based tourism village development becomes important in the sustainable tourism development strategy part. An understanding of sustainable tourism development has emerged as a result of the idea that tourism sustainability depends on the conservation and development of resources used for tourism purposes and various studies and models developed in an effort towards this understanding. The understanding of communitybased tourism is tourism activities that support the traditional way of life of local people and help people gain prosperity by protecting and maintaining social-cultural values and cultural and natural heritage resources. The ownership, management, operation and supervision of this business belongs to the community. Sustainable tourism which is used as an approach to tourism development as a global standard, demands a draft policy that involves the concepts of participation, empowerment, transparency, and justice.

According to UNWTO (2005), concepts such as community participation, empowerment, transparency, justice, equality, and equity need to be integrated into national development regulations and strategies. In developing countries, the majority of the population is a rural community. Therefore a sustainable tourism development strategy with these concepts is more oriented towards rural communities through village development policies with an emphasis on rural tourism. In an effort to empower people 
through tourism development, according to Simson (2008) policies and laws must be developed in such a way that creates real possibilities for local people to play a major role in determining their own benefits from tourism. There is a close link between village development and community socio-economic progress, which can be realized through tourism development in rural areas. A study by Kazimoto (2013) shows that village development strategies are a vital motor in socio-economic development.

In Indonesia, tourism is a strategic sector and becomes a media for the integration of programs and activities between development sectors, so that tourism can potentially become a pioneer of development. Tourism should be encouraged as a pioneer of development because it can create export revenues, create jobs, develop businesses and infrastructure. The scale of rural development priorities based on rural development includes (1) local economic development, (2) community empowerment, (3) development of facilities and pre-facilities, and (4) institutional development.

The success of the development of tourist villages according to location theory, that the factor of closeness to major tourist sites is a distinct advantage for the development of the village into a tourist village (Figure 1). The abundance of visitors from large objects in an area in the surrounding tourist villages is possible because of the proximity of the location to reach several tourist destinations with minimum costs.

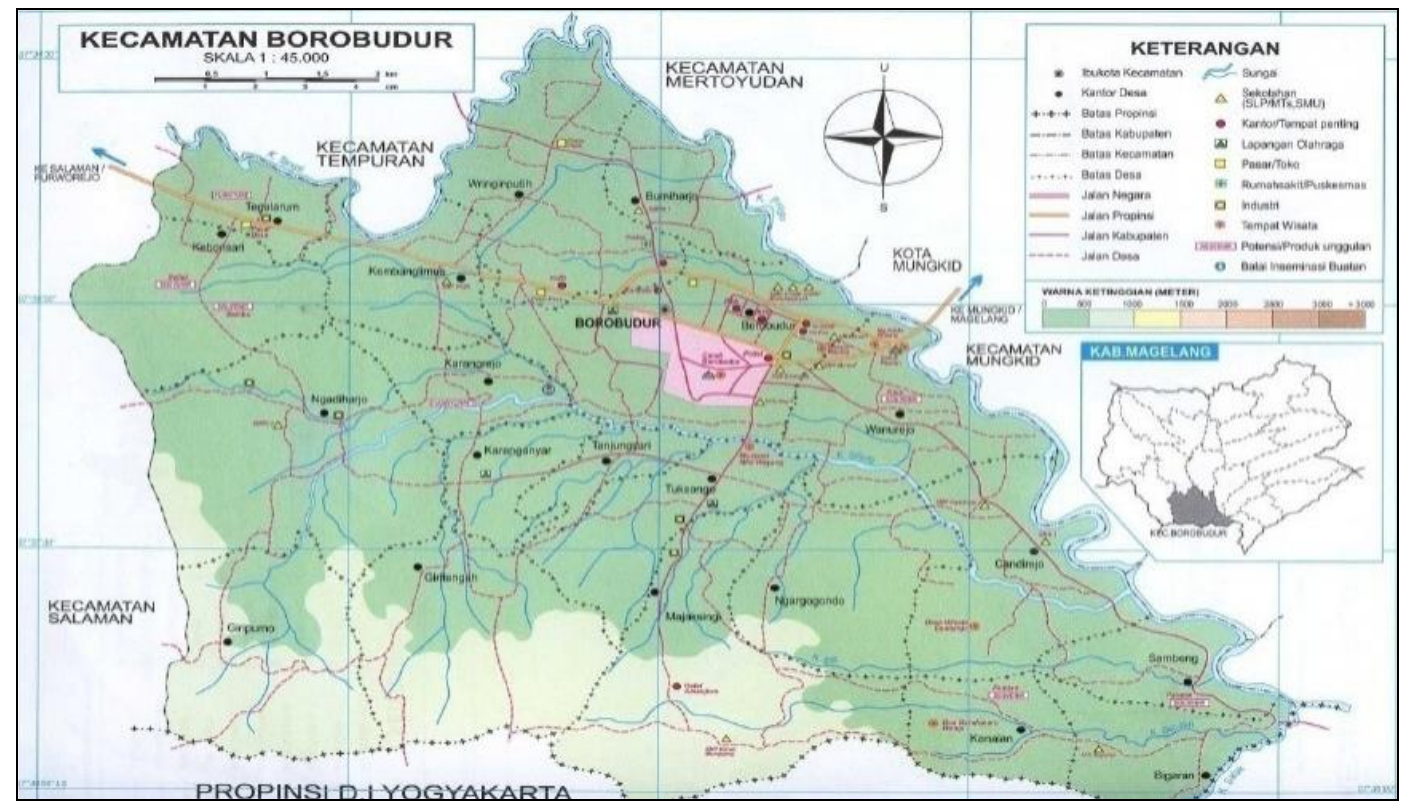

Figure 1. Location of the area of Borobudur Tourism Village

This situation is in accordance with the logic of location theory according to Losch as stated in Krugman (1993), that the farther away from the seller, the more reluctant consumers are to buy goods and vice versa. The abundance of visitors for visits to the surrounding tourist villages is a form of positive externality that can be captured by the village community around the main tourist attractions. Figure 1 shows the increasing trend of tourist visits to Borobudur Temple in the last six years. According to the data, there is an increasing trend of tourist visits to Borobudur Temple from 2013 - 2018, especially experienced by domestic tourists (Figure 2). For foreign tourist visits, although 
it had dropped from 2013 to 2015, after that, foreign tourist visits had increased again in 2017. Increasing tourist visits to Borobudur Temple will be an opportunity for tourist villages around the Borobudur Temple to attract Borobudur Temple visitors to visit tourism villages. The factor of the proximity of the location and the use of their recreational time is an advantage for the surrounding tourist villages because tourist villages are already close to tourists who arrive at Borobudur Temple.

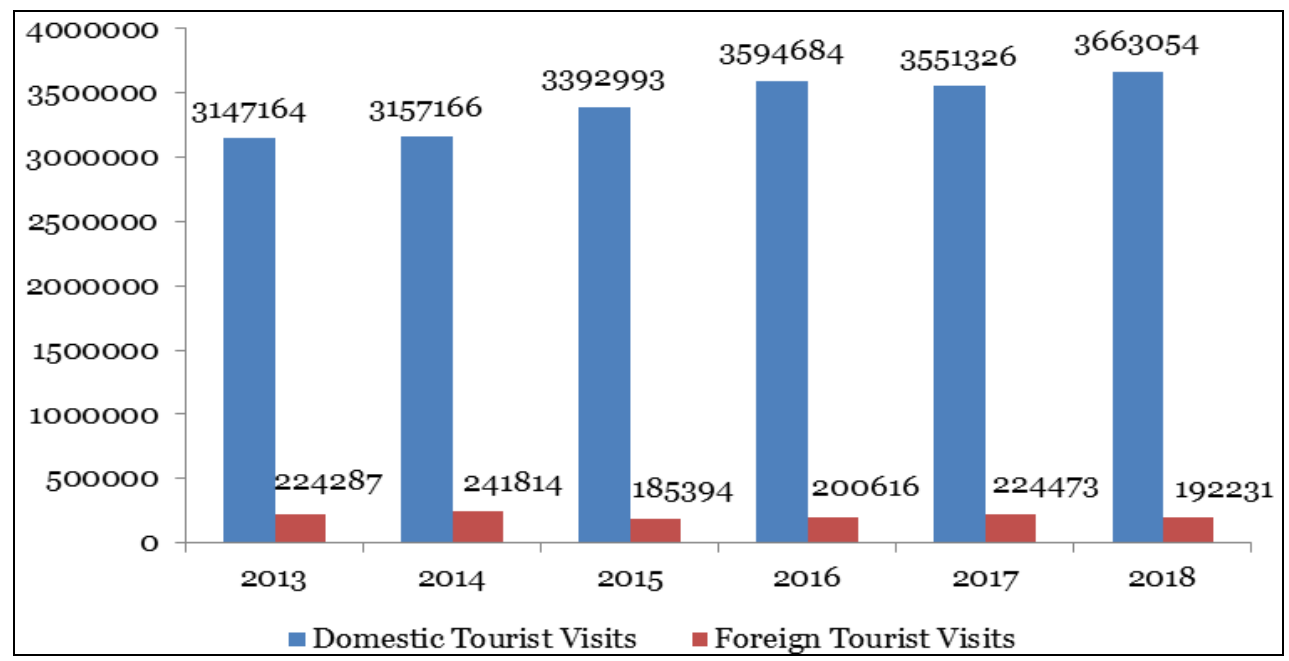

Figure 2. Tourist Visits to Borobudur Temple 2013 - 2018

(Source: Magelang Regency in Figures, 2019)

So far, research on the development of tourism in the Borobudur region is still limited compared to other research outside the Borobudur region in a broader context such as research by Kodir et al. (2019) on tourism governance with the Komodo National Park research area and Junaidi et al. (2019) on halal tourism in Indonesia. Several studies on the development of tourism in the Borobudur region, one of them by Sasana et al. (2017), examines the Borobudur region as a regional tourism cluster with a focus on small and medium industries in supporting tourism. On the other hand, Kausar (2012) studies the Borobudur Temple as a heritage site formed in the management of sustainable world cultural heritage. Likewise, Hermawan et al. (2016) conducted a study of Borobudur Temple as a Buddhist pilgrimage destination in Indonesia by examining the factors influencing visitation intentions. From the explanation, it is necessary to conduct research aimed at analyzing the strategy of community-based tourism villages development as a strategic tourism village area in the Borobudur area, along with the government's focus on Borobudur as a super-priority destination development with enormous costs. With their involvement, the community is able to increase their own incomes, get joint opportunities to improve the welfare of the community, get opportunities to preserve local culture and wisdom and the environment in a sustainable way.

\section{LITERATURE REVIEW}

Rural tourism is considered an appropriate development strategy for rural areas in many developed and developing countries (Ayhan et al., 2020). This development strategy is aimed at agricultural economic growth in addition to preserving existing traditional structures. The aim of developing tourism in rural areas is to increase net benefits for rural 
communities and increase their participation in managing tourism products. If more tourism can be developed in rural areas, especially in ways that involve high local participation in decision making and business, then the impact on poverty reduction is likely to increase (Okech et al., 2012). Local economic development through tourism development strategies can also be done through geoconservation and geotourism which are proven to be able to improve welfare in the karst region as the results of the study of Telbisz et al. (2020). Local economic development with this concept is able to improve welfare that is able to empower the community to get involved in the development of tourism in the region. Furthermore, the concept of community-based geotourism as a tool for local economic development in rural communities can be developed despite challenges (Mukwada \& Sekhele, 2017). According to Avila \& Gasperini (2005), sustainable rural development is understood as a process of constant change and transformation in rural areas, which includes a wide range of processes and programs such as (1) Improved governance at the local, district, and provincial levels, including relations with the private sector, civil society, and government institutions; (2) Development of the productive sector: agriculture, non-agricultural industry, mining, tourism, natural resources, environmental management, and others; (3) Development of institutions and their capacities in key areas, namely education and training, health, research and counseling, marketing, savings and credit, environment, transportation, and others; and (4) Development of rural infrastructure for roads, electricity, telecommunications, housing, water, sanitation, and others.

The concept of community-based tourism village development is generally the concept of development with the tourism sector as a pioneer with village priority scale through community participation in local economic development that empowers communities with the support of infrastructure and institutional development. The tourism-based rural economic development, in this case, is community-based tourism. Community-based tourism is a new form of tourism product where management is carried out by local communities (Osman et al., 2008). Local community participation in managing tourism is carried out at all stages starting from decision making, planning, and evaluation. The community needs to be given a primary role because it is based on the fact that the community itself has knowledge of potential nature and culture and selling points as a tourist attraction, so that community involvement is absolute. Meanwhile, according to Suansri (2003), CBT is tourism that emphasizes environmental, social and cultural sustainability in one package. The development of CBT is managed and owned by the community, for the community, with the aim of enabling visitors to increase their awareness and learn about the community and local ways of life.

In general, community-based development is a development model that provides maximum opportunities for rural communities to participate in tourism development. The concept of CBT means that tourism management is managed by the local community, which includes the overall management of tourism in that location, including the preparation of all products and services needed by tourists. This method allows us to maximize the benefits derived from tourism activities for the local community, as well as placing them as subjects of tourism activities not as objects. The concept of development based on community participation is a concept that supports sustainable development, especially rural development in supporting the independence of villages that support regional independence in the era of regional autonomy. Village economic development is determined not only by internal factors such as endowment, human resources, community culture, but also supported by external factors that can bring up the potential for the economic development of the village. One external factor is the trend in public demand for tourism services today and makes the main tourist destinations abound with 
tourist visits. The results of the study of Xu et al. (2019) postulate four stages of community involvement in sharing benefits and decision making namely the impact recipients, beneficiaries, clients, and owners. However, the reality is that the evolution of participation is slow. This happens because the benefits to the community from tourism and access to the power of decision making are limited. Three suggestions are proposed to overcome this situation, namely capacity building, partnerships, and institutional empowerment.

\section{MATERIALS AND METHODS}

The targets of the study include key community elements which include tourism activists and managers in the village, tourism actors, village officials, youth leaders and people who are broad-minded and influential, relevant and interested parties in the tourist village of Borobudur. This research collects information about opinions and attitudes, important notes, and documentation as supporting information on aspects of strengths, weaknesses, opportunities, and threats of tourist villages development in Borobudur.

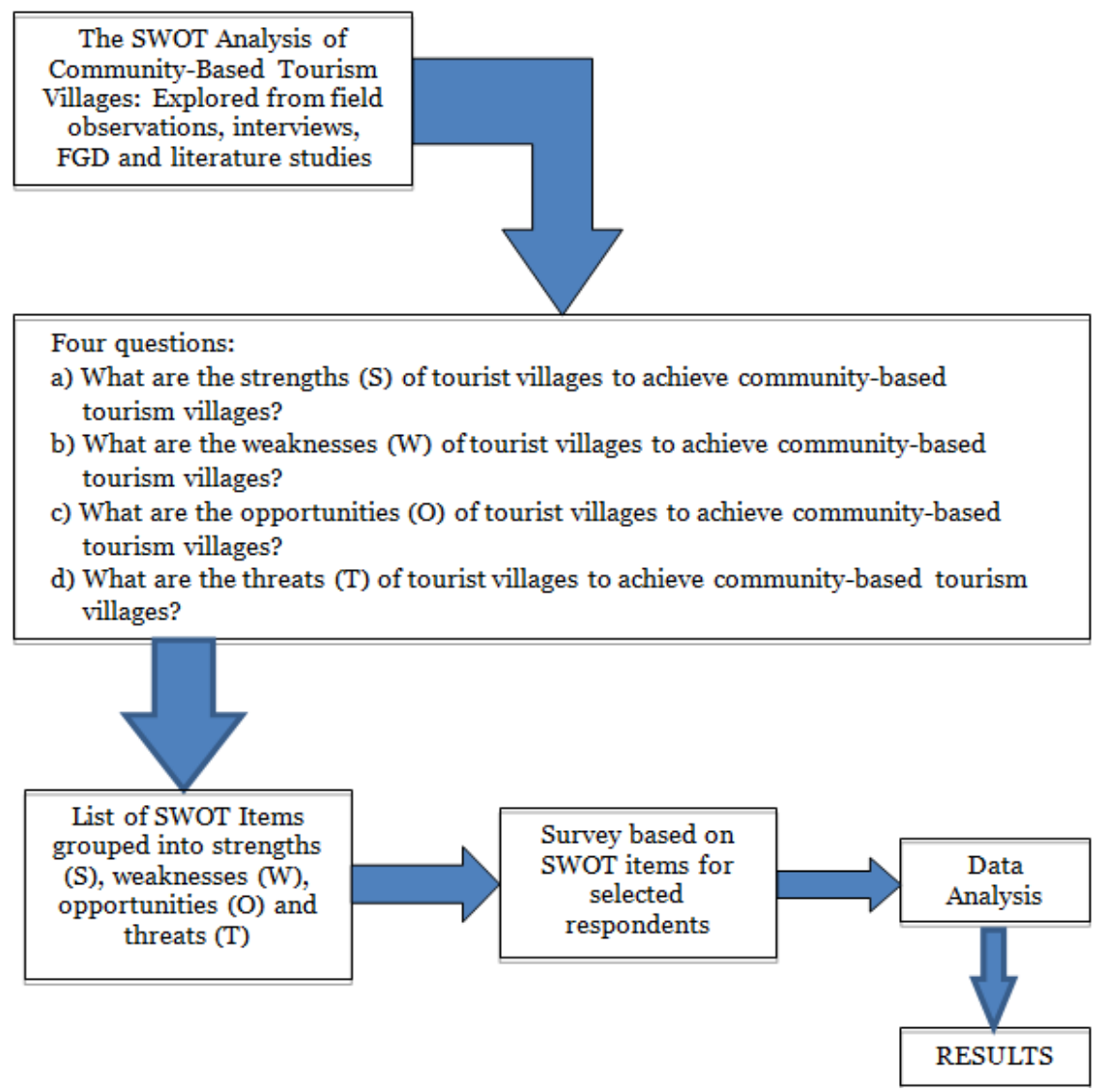

Figure 3. Stages and Processes in Community Based Tourism Village SWOT Research

This research method is a combination of qualitative and quantitative research. This research was conducted to reveal events or facts, phenomena, variables, and circumstances that occurred during the study, but also the use of numbers, starting from data collection, interpretation of the data, as well as the appearance of the results. In 
terms of data collection techniques, this study prioritizes the use of questionnaires as a feature of quantitative research, while conducting observations, interviews and focus group discussions (FGD) reflects qualitative research. From the aspect of mixing as according to Creswell (2009), qualitative and quantitative data are interconnected with each other during the research stages. This study uses analysis of strengths, weaknesses, opportunities, and threats, shortened to SWOT, as the stages and processes are shown in Figure 3. Stages and processes start from the formulation of items in the SWOT analysis that are formulated from information extracted from field observations, interviews, FGDs, and the support of literature review results. The SWOT items are then outlined in a questionnaire delivered to selected respondents, which are proportionally distributed in 20 tourist villages based on the number of key people included in the respondents' criteria.

The results of the SWOT analysis can be used as material to formulate the development strategies with the best-selected policies that are appropriate to the situation in the tourist villages in the Borobudur area. The SWOT analysis generates values related to its ability to see the ways in which internal and external environments interact to influence its success (Houben et al., 1999). Furthermore, the results of the SWOT analysis can also be used for the development and implementation of long-term strategies to achieve certain goals (Houben et al., 1999; Gao \& Peng, 2011; Sevkli et al., 2012).

\section{RESULTS AND DISCUSSION}

\section{Analysis of Strengths, Weaknesses, Opportunities and Threats}

The number of respondents in this study was 93 respondents, whose distribution according to the location is shown in Table 1 . Selected respondents were determined proportionally according to the number of key people who were included in the criteria of 20 tourist villages in the Borobudur area. The results of the survey through questionnaires and interviews with respondents are presented in Table $2-5$.

Table 1. Distribution of Respondents by Location of Tourist Village (Source: Survey data)

\begin{tabular}{|c|c|}
\hline Location of Tourist Village & Number of Respondents \\
\hline Giripurno & 2 \\
\hline Giritengah & 6 \\
\hline Tuksongo & 2 \\
\hline Majaksingi & 3 \\
\hline Kenalan & 3 \\
\hline Bigaran & 2 \\
\hline Sambeng & 3 \\
\hline Candirejo & 6 \\
\hline Ngargogondo & 3 \\
\hline Wanurejo & 2 \\
\hline Borobudur & 17 \\
\hline Tanjungsari & 6 \\
\hline Karanganyar & 6 \\
\hline Karangrejo & 4 \\
\hline Ngadiharjo & 4 \\
\hline Kebonsari & 6 \\
\hline Tegalarum & 4 \\
\hline Kembanglimus & 3 \\
\hline Wringinputih & 7 \\
\hline Bumiharjo & 4 \\
\hline Total & 93 \\
\hline
\end{tabular}


Distribution of 93 respondents based on sex divided into 45 men, and 48 women. The average age of the respondent is 40 years. From the level of education it can be reported that there is one respondent with elementary school education, 9 respondents with junior high school education, 42 respondents with high school education, 25 respondents with diploma education, 15 respondents with undergraduate education, and one respondent with master education. The types of work, they undertake are civil servants, private employees, entrepreneurs, village officials, labor farmers, and others.

Table 2. Level of Importance of Strength Factors in Tourism Villages in the Borobudur Region

\begin{tabular}{|l|c|c|}
\hline \multicolumn{1}{|c|}{ Items } & Total score & $\begin{array}{c}\text { Percentage of } \\
\text { agreement }\end{array}$ \\
\hline The natural beauty of the hills and the countryside & 26.10 & 96.77 \\
\hline The road from the government's project to the village & 19.80 & 100 \\
\hline The richness of traditional arts and culture & 19.28 & 97.85 \\
\hline The Village Economic Center and its complementary facilities & 18.30 & 96.77 \\
\hline Friendliness of the community and mutual cooperation & 13.60 & 98.92 \\
\hline Local wisdom still exists & 13.00 & 100 \\
\hline Crafts and souvenirs & 12.50 & 96.77 \\
\hline Diversity of traditional food and snacks & 6.38 & 98.92 \\
\hline
\end{tabular}

Table 2 - 5 displays the sequence of SWOT items that are grouped into four factors, namely strengths, weaknesses, opportunities, and threats placed in each table. The order of items is based on the total score that has been weighted on the importance level. The importance level score consists of $3=$ most important, $2=$ second importance, and $1=$ second importance. Based on Table 2 the first strength of the results of the SWOT analysis is the natural beauty of the hills and the countryside, which blends with the existence of Borobudur Temple. This has become a major force in developing a strategic tourism area through the proximity of tourist village locations to the presence of Borobudur Temple which is also a major opportunity factor (Figure 4). Therefore the focus of the first priority development strategy is the focus of the strength-opportunity strategy (S-O).

Tourist village objects that have the potential to be developed for the sustainability of the tourist village can not be separated from community involvement as a form of participation as the main actor. Tourism village activities that require community involvement and interaction with tourists in the development of tourism villages are activities related to 1) traditional agricultural activities, such as rice plows and rice planting, yam and papaya picking; 2) animal husbandry activities, for example introduction of honey bee cultivation and goat milk production; 3) handicraft center activities, for example, making miniature of Borobudur Temple and handicraft souvenirs; 4) home industry food activities such as the process of making tofu, vermicelli noodles, slondok, and cassava flakes; 5) traditional arts activities, for example, Gatholoco, Kubrosiswo, Shalawatan, and others; 6) art performances and community traditions aimed at preserving local wisdom such as Saparan and Nyadran which can be packaged to attract tourists; 7) management of homestays originating from residents that allows interaction between tourists and local residents to get to know and learn about the lives and ways of everyday life of people that are not found in the place of origin of tourists.

The second strength factor that supports the development of community-based tourism villages in the Borobudur area is road infrastructure resulting from the development project and improvement of roads leading to tourist villages that facilitate access to tourist villages carried out by the government. This access supports access to tourism objects in the village, especially natural attractions that have been and are 
being developed, and access to enjoy traditional arts and culture, local wisdom of the local community, and various traditional foods and snacks.

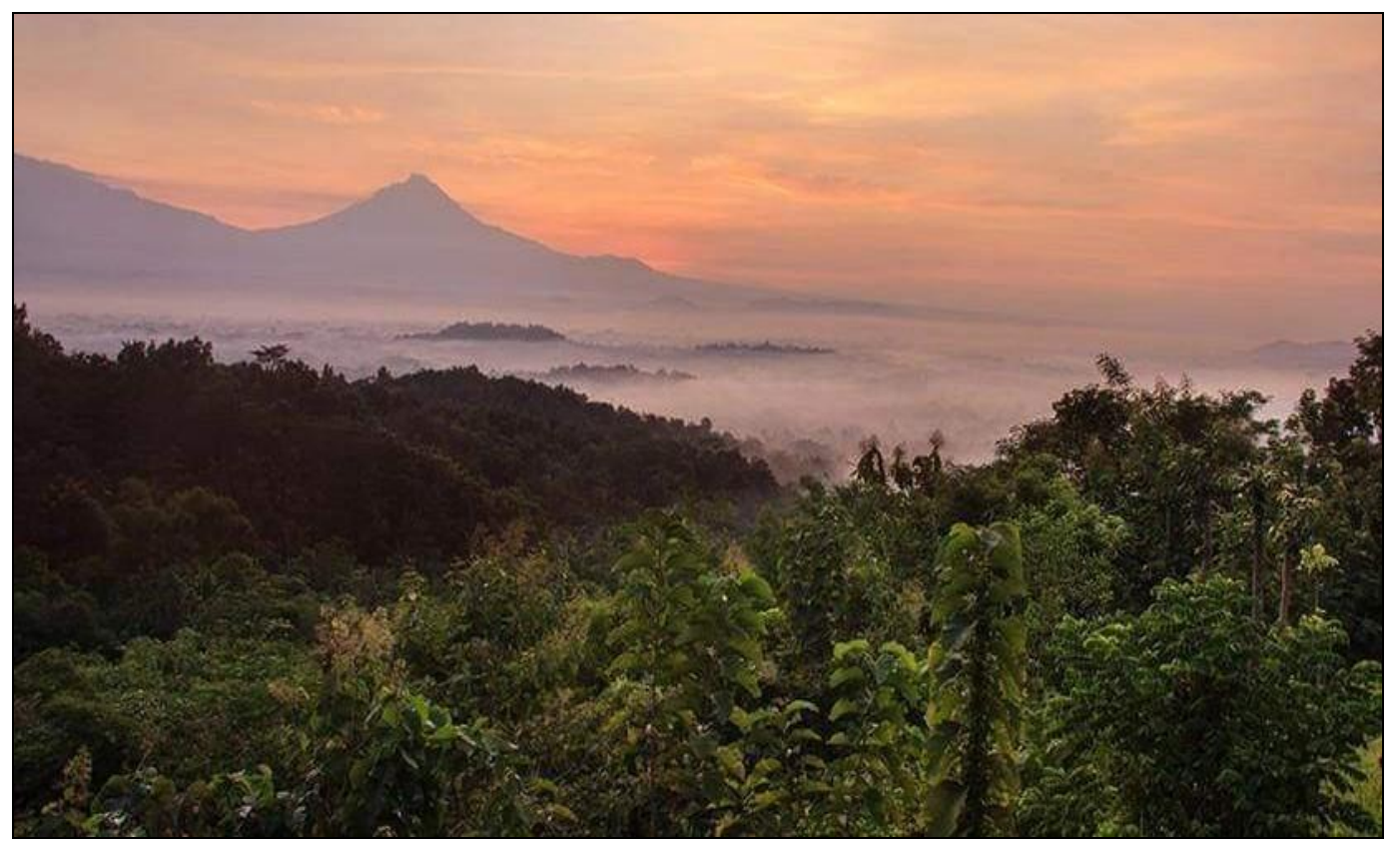

Figure 4. Tourist Attraction of Borobudur Area

The strength factors mentioned are priority strength factors that can be developed and optimized in the Borobudur tourism village development strategy to take advantage of opportunities and overcome existing weaknesses and threats.

Table 3. Level of Importance of Weaknesses Factors in Tourism Villages in the Borobudur Region

\begin{tabular}{|l|c|c|}
\hline \multicolumn{1}{|c|}{ Items } & Total score & $\begin{array}{c}\text { Percentage of } \\
\text { agreement }\end{array}$ \\
\hline Inadequate transportation facilities & 13.00 & 93.55 \\
\hline Limited availability of accommodation and supporting facilities & 12.25 & 92.47 \\
\hline Lack of strengthening networks and communication & 11.85 & 90.32 \\
\hline Promotion of tourism villages has not been maximized & 11.57 & 91.40 \\
\hline Low awareness of environmental cleanliness and waste problems & 10.28 & 94.62 \\
\hline Lack of quality human resources & 10.00 & 90.32 \\
\hline Lack of culinary appeal & 9.52 & 86.02 \\
\hline Lack of cooperation and synergy with stakeholders & 8.40 & 92.47 \\
\hline Lack of supply and availability of clean water in the dry season & 6.50 & 89.25 \\
\hline Lack of community awareness and participation & 6.08 & 91.40 \\
\hline Lack of community motivation and optimism & 5.95 & 88.17 \\
\hline Lack of choice of existing types of attractions & 5.83 & 83.87 \\
\hline Lack of sales and souvenir shops & 5.65 & 88.17 \\
\hline Lack of tourist attractions, especially art performances & 5.63 & 84.95 \\
\hline
\end{tabular}

The weakness factors are more dominated by the problem of inadequate means of transportation and accommodation, lack of strengthening networking and promotion, 
the low quality of human resources in managing tourism businesses. The first factor of weakness in tourism villages is that they are still lacking supporting facilities, as shown in Table 3. The existence of a good road to the tourist village from the results of government projects has not been supported by adequate transportation facilities. Means of transportation are still limited to those provided by tour package providers. So transportation is still incidental if there are tour packages to the destination village. As the next weakness factor that the availability of accommodation in the form of a place or room where tourists can rest, stay, sleep, shower, eat and drink, and enjoy the services and entertainment available is not yet available adequately.

Other factors that are items of weakness are factors related to awareness, attitudes, mentality, and quality of human resources. In addition, institutional factors and the strength of networking and promotion are also lacking.

Table 4. Level of Importance of Opportunities Factors in Tourism Villages in the Borobudur Region

\begin{tabular}{|l|c|c|}
\hline \multicolumn{1}{|c|}{ Items } & Total Score & $\begin{array}{c}\text { Percentage } \\
\text { of agreement }\end{array}$ \\
\hline Proximity to Borobudur Temple & 16.77 & 97.85 \\
\hline $\begin{array}{l}\text { Tourist village as an effort to preserve the arts and culture, and } \\
\text { local wisdom }\end{array}$ & 16.64 & 98.92 \\
\hline Overflow of tourists who enter the Borobudur region & 15.60 & 98.92 \\
\hline Creation of business fields and local people's livelihoods & 15.48 & 98.92 \\
\hline $\begin{array}{l}\text { Tourism is one of the priorities in the development sector by the } \\
\text { government and }\end{array}$ & 13.64 & 95.70 \\
\hline $\begin{array}{l}\text { Government and stakeholder attention to investment and } \\
\text { conservation }\end{array}$ & 12.50 & 97.85 \\
\hline The need for cheap tourism for the community aty & 12.45 & 92.47 \\
\hline $\begin{array}{l}\text { Community favorite trends towards natural attractions and } \\
\text { ecotourism }\end{array}$ & 12.40 & 95.70 \\
\hline $\begin{array}{l}\text { Advances in information technology that provide opportunities } \\
\text { for promotion }\end{array}$ & 11.84 & 100 \\
\hline
\end{tabular}

The main opportunity factor is the proximity of the location of the tourist village to Borobudur Temple as a tourist magnet, as shown in Table 4. In addition, the development of this tourist village provides valuable opportunities in the form of opportunities to preserve the arts and culture, as well as local wisdom which is a tourist attraction in itself.

From the point of view of tourist visitors, it comes out that the abundance of tourists entering the Borobudur region has the potential to be a tourist visit to the surrounding tourist village. The development of a tourism village also provides opportunities in the form of creating a livelihood field for local people. The development of tourism can not be separated from government support in an effort to increase tourism visits through the development of a strategic tourism area. Therefore tourism is one of the priority areas of development by the government will be a special opportunity for the development of tourism villages. This is also supported by the attention of the government and stakeholders in the future investment and conservation of the area. From the aspect of demand for tourism services, the need for cheap tourism for the community makes tourism villages as an alternative visit, as well as an opportunity factor. This is in line with the trend of community interest in natural attractions and ecotourism for the purpose of refreshing and relaxing. The last opportunity factor is the advancement of information technology that provides opportunities for the introduction and promotion of tourism villages. Furthermore, the threat factors are more on the issue of weak partnerships in tourism 
business development, land tenure by investors outside the region, competition with tourism actors outside the region, and natural factors that threaten the sustainability of community-based tourism villages in the future. Based on Table 5 the low involvement and partnership by the private sector in the development of tourism villages can be a threat to the sustainability of tourism villages in the Borobudur region.

Table 5. Level of Importance of Threats Factors in Tourism Villages in the Borobudur Region

\begin{tabular}{|l|c|c|}
\hline \multicolumn{1}{|c|}{ Items } & $\begin{array}{c}\text { Total } \\
\text { Score }\end{array}$ & $\begin{array}{c}\text { Percentage } \\
\text { of agreement }\end{array}$ \\
\hline The low involvement and partnership with the private sector & 20.32 & 87.10 \\
\hline Expansion of outside investors in land ownership & 20.16 & 81.72 \\
\hline Increased competition with private providers & 18.72 & 89.25 \\
\hline Lack of consideration of the environmental impact of the project & 18.15 & 88.17 \\
\hline Natural factors such as drought and landslide vulnerability & 17.43 & 90.32 \\
\hline Lack of tourist information & 12.45 & 91.40 \\
\hline The uncertainty of the number of tourist visitors due to seasonal factors & 11.50 & 83.87 \\
\hline
\end{tabular}

Furthermore, the strength of outside investors in the expansion of land ownership in the Borobudur region is the second threat. Competition in the provision of artificial tourism by private or individuals is also a threat. At this time the rise of tourism service offers has increased competition and become a threat to the sustainability of tourism villages if they do not improve the quality of tourism services.

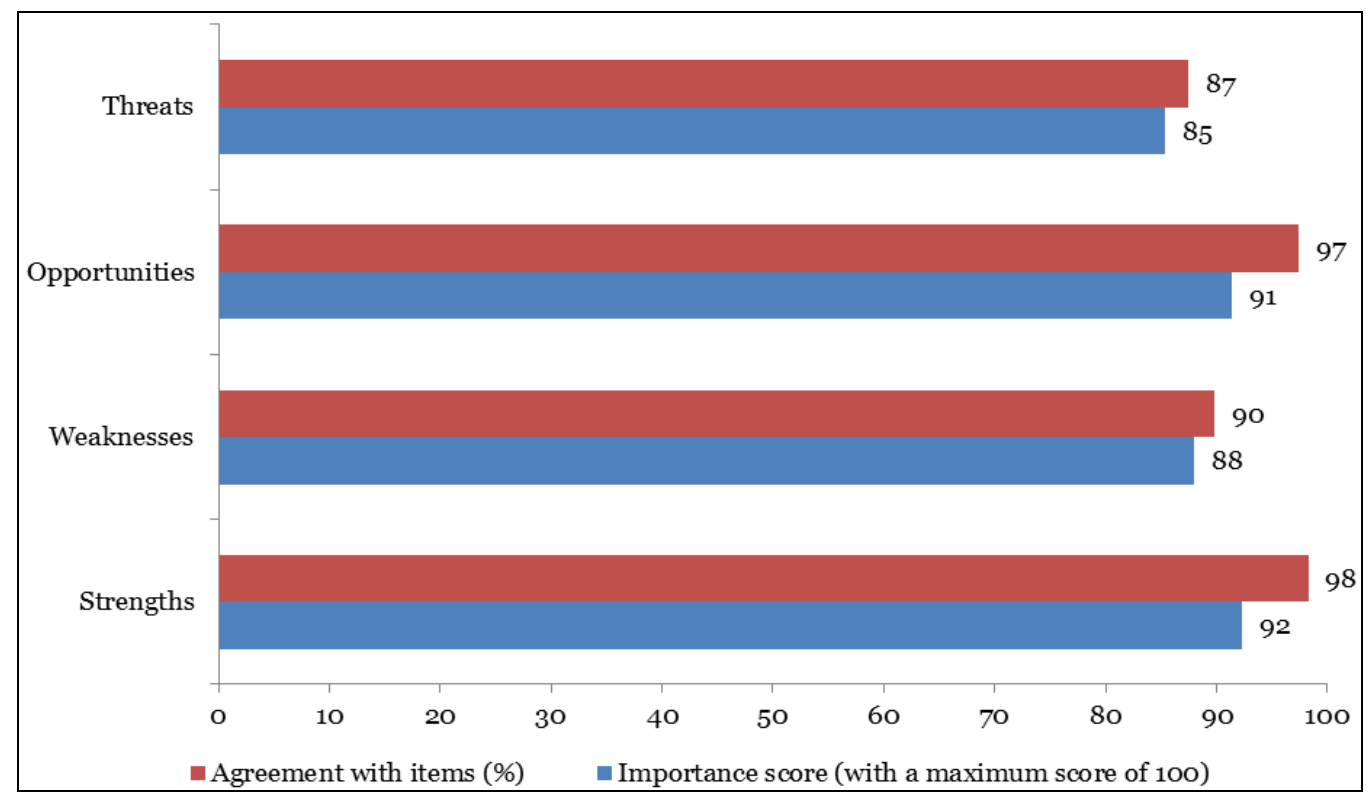

Figure 5. Importance Score and Agreement Percentage of Items in the Group of Strengths, Weaknesses, Opportunities and Threats Factors of Community-Based Tourism Village Development in the Borobudur Area

Other threat factors are related to environmental problems. The lack of consideration of the environmental impact of the resort and hotels project poses a threat to the sustainability of the tourism village. Other threats related to the environment are 
natural factors with a dry season that affect drought and rainy season prone to landslides. The next threat is the lack of tourist information. The last two factors of threat are lack of knowledge and information about the tourist village of Borobudur and the number of daily tourist visits that are uncertain due to seasonal factors.

\section{Development Strategies}

Based on the results of the SWOT analysis, the tourism village development strategy must consider the score ranking of the importance of each factor as carried out in research by Bull et al. (2016). Figure 5 shows that the importance level score for the strength factor is the highest with a score of 92, followed by an opportunity factor with a score of 91, and subsequently, the weakness and threat factors respectively with a score of 88 and 85 . The score is a converted score with the reference a maximum score of 100.

This calculation is to compare together with the percentage of the agreement which each is in the same order with the importance level. There is a correlation between the score of importance level and the percentage of agreement.

These results indicate that the opinions and attitudes of the respondents are consistent so that it supports the validity of the results of this survey. The multiplication results between the scores of the importance level between groups of factors as shown in Figure 5, and then the results are divided by 100 to simplify, the results obtained as shown in Figure 6. The results of this multiplication reflect the strength of interaction between the strength-opportunity (SO), weakness-opportunity (WO), strength-threat (ST) and weakness-threat (WT) factors. Furthermore, the results of this interaction can be used as a basis for determining the priority focus of the strategy in developing community-based tourism villages in the Borobudur region.

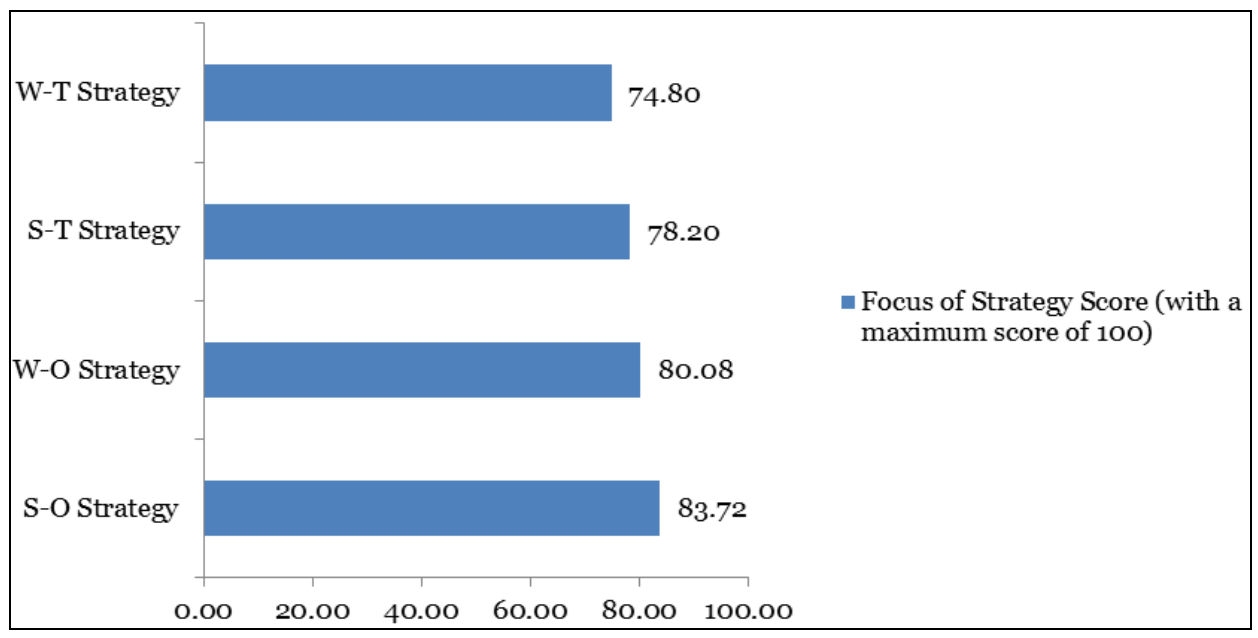

Figure 6. Ranking and Scores of Strategy Focus in the Development of Community-Based Tourism Villages in the Borobudur Area

Figure 6 shows that the interaction of strengths and opportunities provides the highest score, followed successively by the weakness-opportunity interaction score, the strength-threat interaction score, and the weakness-threat interaction score. The above description implies that community-based tourism village development strategies can be carried out with more emphasis on strategies that rely on strengths and opportunities, through S-O and W-O strategies, relative to weaknesses and threats, through S-T and W- 
$\mathrm{T}$ strategies. However, in the implementation of the four strategies are still carried out because they will complement each other in order to achieve the goal of developing a sustainable tourism strategic area by considering a number of components of rural tourism development as stated by Gunn (1988), Wilson et al. (2001), Avila \& Gasperini (2005), Everett \& Aitchison (2008), Petrović et al. (2017), and Xu et al. (2019).

The focus of strategy based strengths and opportunities becomes the focus of the first strategy. The implementations of the focus of the strength-opportunity strategy based on the results of the SWOT analysis in the development of community-based tourism villages are as follows:

a. Strengthening tourism institutions in the Borobudur region involving the government, the private sector and the community as well as a collaboration so that there is synergy and integration between tourism stakeholders facilitated by the local government through special agencies and the central government through the ministry, which in charge of tourism.

b. Continuation of government projects in building road infrastructure to reach tourism objects in villages, especially natural tourism objects that have been initiated and carried out by the community.

c. Collaboration between the community, regional and central government, and the private sector in developing activities to promote local arts and culture and efforts to preserve local wisdom to attract village tourism through routine events in the form of local cultural and tourism festivals, tourist village, and tourism awareness group festivals.

d. Sustainability of support programs from State-Owned Enterprises, where Private Business Entities can take part in the same program, for village tourism development activities that have been preceded by the establishment of the Village Economy Center to activities oriented to improving the skills and ability of tourism business management to the community for independence and sustainability in the future.

The focus of weakness and opportunity based strategies becomes the focus of the second strategy. The implementations of the focus of the weakness-opportunity strategy based on the results of the SWOT analysis are as follows:

a. Development of tour packages that provide opportunities for cooperation in the provision of transportation with transportation providers such as community networks and tourism actors, especially traditional transportation such as andhong, ancient cars, and ancient bicycles to surround and visit tourist destinations. The use of selected transportation modes and road routes to the destination attractions become part of the tour package.

b. Development of tourism awareness groups that do not yet exist, and strengthening the positions and roles of existing tourism awareness groups, so that they are available in each tourism village, with facilitation from the government, both at the initiative of the community and initiatives of local government agencies which in charge of tourism. With regard to the existing tourism awareness groups, strengthening tourism awareness groups can be done by increasing the guidance of both the central and regional governments, other elements consisting of the private sector, industry and tourism associations. Coaching mainly through direct coaching that can be done through talks, discussions, education and training, workshops, competitions, and others.

c. Increasing and strengthening cooperation between managers of village tourism activities with stakeholders and other tourism actors in the village tourism promotion program, both through special events, advertisements in electronic media and outdoor media such as billboards, posters, banners and so on. 
d. Improving the quality of human resources and entrepreneurial skills in the development and management of tourism businesses for tourism managers and activists in each tourist village facilitated by the central and regional governments in collaboration with private elements engaged in tourism businesses. With this effort, the village's potential consisting of natural attractions, arts, and culture, crafts, food, and special culinary can be developed as part of the village tourism business.

e. Strengthening the institutional relationship between the village government, the community, and activists and tourism managers so as to create strength and synergy in the development of tourism villages based on a spirit of togetherness and prioritizing common interests and transparency in each of their activities.

Based on the analysis of the results of the strength and threat item scores, the focus of the strength-threat strategy becomes the third strategy focus. The implementations of this strategy focus include:

a. Development of cooperation between tourism managers in the tourism village with private parties engaged in tourism, both in the management of tourism businesses and in promotion and marketing, through the development of tour packages in capturing the tourist market destination of Borobudur and surrounding areas.

b. Improvement of the tour package services and their promotion through cooperation with other parties, by every tourism business manager in the village so that tourists can get the satisfaction that makes them come back again and recommend to others to come to visit.

The focus of the weakness-threat strategy becomes the fourth strategy focus on the development of community-based tourism villages in the Borobudur region. The implementations of the focus of the strategy are as follows:

a. The establishment of a communication and cooperation forum between the tourism village managers so that each other can develop complementary tourism businesses and not to lethal competition, for future business sustainability in the tourism product market competition with tourism actors outside the region.

b. Improvement of clean water supply projects either through the follow-up and the realization of the expansion of the clean water supply service network by the local government through regional water supply companies, as well as through self-based partnership programs and community participation to support the development of tourist villages in every village in the Borobudur region.

c. Strengthening the role of the village government, sub-district government and regional government agencies in regulating land ownership in villages in the Borobudur District area, as the enforcement of government regulations for higher government, in this case, the Ministry of Agrarian and Spatial Planning/Head of the National Land Agency to preventing the expansion of agricultural land tenure by investors from outside the area. Land tenure by outside regional investors and misuse of agricultural land will narrow the space for community participation as the main actors in the development of community-based tourism villages in the future.

d. Enforcement of firmer regulations on the environmental impact of construction projects for hotels, resorts and other projects located in the tourism village area carried out by local government agencies in charge of the environment.

\section{CONCLUSIONS}

The development of community-based tourism villages in the Borobudur region as part of a strategic tourism area at least pays attention to aspects of the village potential, human resources, institutions, partnerships, promotions, and networks. All of 
these aspects will be the target of developing tourist villages by providing more space for local community participation in each aspect. Village potential, especially natural objects that are inseparable from the existence of Borobudur Temple, along with the diversity of arts and culture, traditional handicrafts and food as well as local wisdom that still survive, can be integrated with other aspects.

Based on the results of the SWOT analysis, the development strategies of the tourism village prioritize the focus of the strength-opportunity strategy as the main strategy. Strengthening tourism institutions from the village, sub-district, district, provincial and central levels will greatly determine the success of the development of tourism villages towards a strategic tourism area that is supported by community participation and cooperation with the private sector. In addition, the existence of tourism awareness group in the village is no less important in the development of tourism villages because community participation in the development of tourism villages starts from the existence of tourism awareness group starting from the initiation, planning, implementation, supervision, and evaluation stages in village tourism business activities.

Three strategies focusing on weaknesses-opportunities, strengths-threats, and weaknesses-threats complement the strategy that focuses on strengths and opportunities in achieving the objectives of all aspects of the development of tourist villages in the Borobudur region. Therefore, with these four strategies, the development of tourist villages will be able to optimize the potential of existing villages with supporting resources, strong institutions, accompanied by strengthening partnerships and networks in the management of tourism businesses and their marketing and promotion for the sustainability of tourism villages in the future.

\section{Acknowledgements}

Acknowledgments to General Directorate of Strengthening Research and Development, Ministry of Research, Technology and Higher Education, who have provided opportunities and financial assistance to carry out research with the National Strategic Research Scheme in 2019.

\section{REFERENCES}

Ahyan, Ç.K., Taşlı, T.C., Özkök, F. \& Tatli, H. (2020). Land Use Suitability Analysis of Rural Tourism Activities: Yenice, Turkey. Tourism Management, 76(2020) 103949 https://doi.org/10.1016/j.tourman.2019.07.003.

Avila, M. \& Gasperini, L. (2005). The MDGs and Sustainable Rural Development in sub-Saharan Africa: Challenges and Implications for Education for Rural People. Paper of Ministerial Seminar on Education for Rural People in Africa: Policy Lessons, Options and Priorities, 7-9 September 2005, Addis Ababa, Ethiopia.

Archer, B., Cooper, C. \& Ruhanen, L. (2005). Global Tourism (William F. Theobald Editor), The Pesitive and Negative Impacts of Tourism, Third Edition, London: Butterworth-Heinemann, (2005), 79- 102.

Bull, J.W., Jobstvogt, N., Böhnke-Henrichs, A., Mascarenhas, A., Sitas, N., Baulcomb, C., Lambini, C.K., Rawlins, M., Baral, H., Zähringer, J., Carter-Silk, E., Balzan, M.V., Kenter, J.O., Häyhä, T., Petz, K. \& Koss, R. (2016). Strengths, Weaknesses, Opportunities and Threats: A SWOT Analysis of the Ecosystem Services Framework. Ecosystem Services, 17, 99-111.

Creswell, J.W. (2009). Qualitative, Quantitative, and Mixed Methods Approaches. Third Edition. Thousand Oaks California: @SAGE Publications.

Choi, H.S.C. \& Sirakaya, E. (2005). Measuring Residents' Attitude Toward Sustainable Tourism: Development of Sustainable Tourism Attitude Scale. Journal of Travel Research, 43(4), 380-394.

Everett, S. \& Aitchison, C. (2008). The Role of Food Tourism in Sustaining Regional Identity: A Case Study of Cornwall, South West England, Journal of Sustainable Tourism, 16(2), 150-167.

Gao, G.Y. \& Peng, D.H. (2011). Consolidating SWOT Analysis with Nonhomogeneous Uncertain Preference Information. Knowledge-Based Systems, 24(6), 796-808.

Gunn, C. A. (1988). Tourism Planning. 2d ed. New York: Taylor and Francis. 
Hermawan, B., Salim, U., Rohman, F \& Rahayu, M. (2016). Borobudur Temple as Buddhist Pilgrimage Destination in Indonesia: an Analysis of Factors that Affect Visit Intention. Journal of International Buddhist Studies, 7(2), 98-110.

Hiwasaki, L. (2006). Community-based tourism: A Pathway to Sustainability for Japan's Protected Areas. Society \& Natural Resources, 19 (8), 675-692.

Houben, G., Lenie, K., \& Vanhoof, K. (1999). A Knowledge-Based SWOT-Analysis System as an Instrument for Strategic Planning in Small and Medium Sized Enterprises. Decision Support Systems, 26(2), $125-135$.

Junaidi, J., Suci, A., Nanda, S.T., \& Kadaryanto, B. (2019). Halal-Friendly Tourism Business Process: Tourism Operators in Indonesia. GeoJournal of Toursm and Geosites, 27(4), 1148-11157. https://doi.org/ 10.30892/gtg.27403-422 .

Kazimoto, P. (2013). The Effect of Village Development Strategies on Community Socio-Economic Development in Tanzania, Arumeru District. International Journal of Research in Social Sciences, 2(3), 33-39.

Kausar, D.R. (2012). Sustainability in the Management of World Cultural Heritage. Vision for Global Tourism Industry-Creating and Sustaining Competitive Strategies, Chapter April 2012, 431-440.

Kodir, A., Tanjung, A., Sumarmi, Ahmad, R., \& Simanjuntak, T.B. (2019). Tourism Governance in Komodo National Park, Indonesia: Blessing or Curse?. GeoJournal of Toursm and Geosites, 27(4), 1401-1417. https://doi.org/10.30892/gtg.27424-443.

Komppula, R. (2014). The Role of Individual Entrepreneurs in the Development of Competitiveness for A Rural Tourism Destination-A Case Study, Tourism Management, 40, 361-371.

Krugman, P.R. (1993). On the Relationship between Trade Theory and Location Theory, Review of International Economics, 1, 110-122.

Muganda, M., Sahli, M., \& Smith, K.A. (2010). Tourism's Contribution to Poverty Alleviation: A Community Perspective from Tanzania, Development Southern Africa, 27 (5), 629-646.

Mukwada, G. \& Sekhele, N. (2017). The Potential of Community-based Geotourism in Rural Development in South Africa: The Case of Witsie Cave Project. Journal of Asian and African Studies, 52(4), 471-483. https://doi.org/10.1177/0021909615595991.

Okech, R., Haghiri, M. \& George, B.P. (2012). Rural Tourism as A Sustainable Development Aalternative: An Analysis with Special Reference to Landa, Kenya, Culture, Special Issue, 6(3), 36-54.

Osman, I., Ahmad, Z.A., Ahmad, N.H., Khin, S., Abu Bakar, S., Husin, A., \& Tanwir, N.D. (2008). Participation of Women Entrepreneurs in Ecotourism Industry: A Proposed Model. In RARC 22 International Conference 2008. Knowledge Infrastructure Management from Tourism Penang Malaysia 3-4 November 2008. RIKKYO Amusement Research Centre. Tourism Project Series (02), 212-223.

Petrović, M.D., Lukić, D., Radovanović, M., Vujko, A., Gajić, T. \& Vuković, D. (2017). "Urban geosites” as potential geotourism destinations-Evidence from Belgrade, Open Geosci, 9(1), 442-456.

Sasana, H., Atmanti, H.D. \& Muid, D. 2017. The Strategy Development of the Region in Support Borobudur Tourism Cluster Competitiveness Regions in Indonesia. Journal of Environtmental Management and Tourism, 8(24), 1517-1528.

Sevkli, M., Oztekin, A., Uysal, O., Torlak, G., Turkyilmaz, A. \& Delen, D. (2012). Development of A Fuzzy ANP based SWOT Analysis for the Airlane Industry in Turkey. Expert Systems with Applications, 39(1), $14-24$.

Simson, M.C. (2008). Community Benefit Tourism Initiatives-A Conceptual Oxymoron? Tourism Management, 29(1), 1-18.

Suansri, P. (2003). Community Based Tourism Handbook. Thailand: REST Project.

Telbisz, T., Gruber, P., Mari, L., Kőszegi, M., Bottlik, Z., \& Standovár, T. (2020). Geological Heritage, Geotourism and Local Development in Aggtelek National Park (NE Hungary). Geoheritage, 15:2 https://doi.org/10.1007/s12371-020-00438-7

Wilson, S., Fesenmaier, D.R., Fesenmaier, J. \& Van Es, J.C. (2001). Factors for success in rural tourism development, Journal of Tourism Research, 40(2), 132-138.

$\mathrm{Xu}$, H., Jiang, F., Wall, G., \& Wang, Y. (2019). The Evolving Path of Community Participation in Toursm in China. Journal of Sustainable Tourism, 27(8), 1239-1258. https://doi.org/10.1080/09669582.2019.1612904.

Yanes, A., Zielinski, S., Cano, M.D. \& Kim, S. (2019). Community-based tourism in developing countries: A framework for policy evaluation, Sustainability, 11(2506), 1-23.

*** UNWTO-United Nations World Tourism Organization. (2005). Making Tourism More Sustainable: A Guide for Policy Makers; UNWTO: Madrid, Spain.

https://magelangkab.bps.go.id/publication/2019/o8/16/1a198c1edcadcfaof6768b82/kabupaten-magelangdalam-angka-2019.html accessed 25.10.2019

Submitted:

09.12.2019
Revised:

25.03.2020
Accepted and published online 01.04.2020 